\title{
VII. Experiments respecting the effects of quicksilver on vegetable life
}

\section{Von Deimann , Paats Van Trostwyk \& Lauwerenburgh}

To cite this article: Von Deimann , Paats Van Trostwyk \& Lauwerenburgh (1799) VII. Experiments respecting the effects of quicksilver on vegetable life, Philosophical Magazine Series 1, 4:14, 161-163, DOI: 10.1080/14786449908677048

To link to this article: http://dx.doi.org/10.1080/14786449908677048

曲 Published online: 18 May 2009.

Submit your article to this journal $\sqsubset \pi$

Џ Article views: 2

Q View related articles $\square$ 
VII. Experiments refpecting the Effects of Quickfilwer oxt Fegetable Life. By Von Deimann, PaAts Vax TROSTWYK and LAUWERENBURGH*.

$\mathrm{E}$ XPER. I. A plant of the fmall garden bean, which had grown in the open fields, was placed in water clofe to a flak filled with quickfilver one inch in diameter, and the water was covered by a bell twelve inches in height and fix in diameter.

II. A plant of curled mint, the root of which ftood in water, was placed with quickfilver under a bell eight inches in height and four and a half in diameter.

III. The firt experiment was repeated, with this variation; that the bell, inftead of fanding over water, was placed on a dih, and fupported by pieces of cork.

IV. The fame experiment as the fecond, with this difference; that pieces of leaf gold were fufpended in the bell.

V: A flafk filled with quicklilver was placed clofe to fome young plants of the fircea falicifolia, which ftill adhered to the parent root, and the whole was covered with a bell.

VI. The fecond experiment was repeated, and a little fulphur was applied to the interior fides of the bell.

VII. The fecond experiment again repeated, with this difference; that the quickilver was covered with a little water.

VIII. A plant of the curled mint was placed in a bafon. of water with a little quickfilver, in fuch a manner that the roots were in contact with the metal.

IX. The roots of a bean plant, which had thot out through holes made in the pot in which it had been reared, were placed in a flat dilh filled with quickfilver.

$\mathrm{X}$. Some beans were planted in earth mixed with quickfilver.

XI. A plant of tise curled mint was placed in a bafon with water, and red oxyd of mercury prepared with the

* From Scherer's Allgemwines Gournal der Cbemie, Vol. I. No. 6. Vox. IV. 
nitrous acid which had been wafhed firft with an alcaline folution and then with pure water, the roots being immer fed in the oxyd.

XII. The fame as the fecond, with this variation; that inftead of quickfilver the oxyd was ufed.

XIII. Beans were planted in a mixture of earth and the red oxyd of quickfitver. lead.

XIV. The fame planted in earth mixed with the oxyd of

$\mathrm{XV}$. Of three plants of the curled mint, one was placed, in the fame manner as in the IIth experiment, in a phial which contained water and the oxyd of manganefe; the fecond in another, containing water and the oxyd of copper; and the third in one containing water and the oxyd of lead.

The leaves and ftems in the experiments $1,2,3,4$, and 5 , were on the third day covered with black fpots; and on the fourth, fifth, and at mot the fisth, had become entirely black. The young tree in the $5^{\text {th }}$ experiment could not hold out the whole fummer, though it ftood connested with the parent plant. 'The plants died fo completely that the leaves frequently dropped or, and the flem funk down the very moment the bell was removed. The plants in the 6th experiment remained without any change, which hews that fulphur prevents the bad effects of the quickfilver. In the $7^{\text {th }}$ experiment the effect of the quickfilver was deftroyed, on account of the water by which it was covered.

The experiments 8,9 , and 10 , prove that the quicksilver, when mixed with earth or water, or when it fands in contact with the roots of plants, is in no manner prejudicial to them.

The I th experiment, which we repeated feveral times, thewed us that the oxyd of quickllver, placed in contact with the roots of a plant, is deftructive to it. This oxyd, however, did not produce the fame effect when it was placed as the metallic quickfilver, near to the plant; as was proved by the rath experiment, in which the plant did not experience the leaft change. 
In the 15 th experiment the plants were not in the leaft affected by the different oxyds; which proves that plants, like animals, feem capable of being accuftomed to thing pernicious to them, provided they begin at infancy. The beans planted in earth mixed with the oxyd of quickfilver grew up, but fo weak and ftunted that they could farcely be known. Thofe, bowever, which had been planted at the fame time as the former in a mixture of earth and the oxyd of lead, thot up as ufual, and exceeded them in frength and weight more than four times.

In thefe refearches we were at great pains to make fome comparative experiments, and we found that the plants in thofe where no quickfilver was employed, lived a confiderable time in a ftate of perfect vegetation. Thefe refults we give merely as facts, without attempting at prefent to explain them. A confiderable quantity of quickfilver placed in a very confined atmofphere may be equally pernicious to animal exiftence, as we think ourfelves authorifed to infer from feveral experiments, the courfe of which the late feafon of the year obliged us to fufpend, and from which it appears that, in one point of view, things hurtful to animals are hurt-o ful alfo to plants.

VIII. Obfervations on Animal Eledricity; being tbe Subfance of two Letters from A. VOLT A to Profeffor GREN.

[Concluded from Page 68.]

7 HE very confiderable difference in regard to the quantity of effect in the before-mentioned experiments already hews, that if the electric fream excited by contact is ftrongeft towards a certain metal, when that metal is placed between a certain fluid on the one fide, and another fluid on the other, there are other fluids which produce a greater effect with another kind of metal; fo that it will be necef. fary to difcover by experiment the particular arrangement of 